\title{
ANALISIS PENGARUH FAKTOR-FAKTOR MODAL INTELEKTUAL TERHADAP KINERJA KEUANGAN PADA PERBANKAN YANG TERDAFTAR DI BURSA EFEK INDONESIA
}

(Studi Empiris Pada Bank-Bank yang sudah go public dan selalu memperoleh Laba Periode tahun 2010 - 2014)

\author{
SIARWI \\ Universitas Pamulang \\ Email : alfinasywa@yahoo.com
}

\begin{abstract}
The purpose of this research is to know the effect of Human Capital element, Structural Capital and Capital Service to Return On Assets (ROA) either partially or simultaneously in banking company that has go public and always make a profit during the period of 2010 - 2014. The research method used is proportionate stratified random sampling, with sample of 22 banks and data obtained from Bank Indonesia. Analysis technique used is multiple regression analysis by using Eviews 7.0 software for regression analysis and hypothesis test, because data used is panel data, that is data that combine time series and cross section data. The results showed that Human Capital Elements have positive and significant impact on Return On Assets (ROA) of $82.69 \%$ and the rest of $7.31 \%$ influenced by other factors. Structural Capital (Structural Capital) has a positive and significant impact on Return On Assets (ROA) of $81.82 \%$. and the remaining $18.18 \%$ influenced by other factors, from the Capital Elements Services (Customer Capital) have a positive and significant impact on Return On Assets (ROA) of $84.50 \%$ and the remaining $15.50 \%$ influenced by other factors. Based on the results of Eviews output obtained $F$ table of 2.40. Thus Fcount> Ftable (25.74514> 2.40), then seen from the value of Probability ( $F$-statistic) is 0,0000, smaller than 0.05 or $0.000<0.05$, so $\mathrm{HO}$ is rejected and $\mathrm{HI}$ accepted. It is that the variables of Human Capital Elements (Human Capital), Structural Capital (Capital Structural), Capital Capital Service (Customer Capital) simultaneously (together) have a significant influence on Return On Assets (ROA). With multiple regression equation is: $Y=0.015-0.00047 X 1+5.99 X 2+0.0128$ X3
\end{abstract}

Keywords: Human Capital, Structural Capital, Capital Capital and Return On Assets (ROA). 


\section{LATAR BELAKANG MASALAH}

Di Indonesia, Intellectual Capital mulai berkembang setelah muncul PSAK No, 19 tentang aktiva tidak berwujud. Menurut PSAK No,19, aktiva tidak berwujud adalah aktiva non -moneter yang dapat diidentifikasi dan tidak mempunyai wujud fisik serta dimiliki untuk digunakan dalam menghasilkan atau menyerahkan barang atau jasa, disewakan kepada pihak lainnya,atau untuk tujuan administratif (IAI,2002).

Sampai saat ini pengukuran Intellectual Capital sendiri masih terus berkembang sehingga belum adanya standar khusus bagi pengukuran ini. Pulic $(1998 ; 1999)$ tidak mengukur secara langsung Intellectual Capital perusahaan, tetapi menawarkan suatu ukuran untuk menilai efisiensi dari nilai tambah yang merupakan hasil dari kemampuan intelektual perusahaan (Value Added Intellectual Coefficient-VAIC $\left.{ }^{t m}\right)$. Tujuan utama dalam ekonomi yang berbasis pengetahuan adalah untuk menciptakan nilai tambah (value added). Sedangkan untuk menciptakan nilai tambah dibutuhkan ukuran yang tepat physical capital (yaitu dana-dana keuangan) dan intellectual capital (direpresentasikan oleh karyawan dengan segala potensi dan kemampuan yang melekat pada mereka).

VAIC $^{\mathrm{tm}}$ menunjukan bagaimana sumber daya perusahaan, yaitu physical capital (VACA - value added capital employed), human capital (VAHU - value added human capital), dan structural capital (STVA -structural capital value added) telah secara efisiensi dimanfaatkan oleh perusahaan.

Hubungan antara modal capital $\left(\mathrm{VAIC}^{\mathrm{tm}}\right)$ dengan kinerja keuangan telah dibuktikan secara empiris oleh Firer dan Williams (2003), Belkaoui (2003) dan Tan et al. (2007) yang membuktikan modal intelektual berpengaruh positif pada kinerja keuangan. Salah satu area yang menarik perhatian akademisi maupun praktisi adalah terkait dengan kegunaan modal intelektual sebagai salah satu alat untuk menentukan nilai perusahaan (Edvinsson dan Malone 1997).

Maka berdasarkan uraian di atas peneliti memilih judul penelitian ini adalah "Analisis Pengaruh Faktor-faktor Modal Intelektual terhadap Kinerja Keuangan pada Perbankan yang terdaftar di Bursa Efek Indonesia" Tahun 2010-2014.

\subsection{Rumusan Masalah}

Berdasarkan pembatasan masalah di atas, maka dapat dirumuskan masalah dalam penelitian ini adalah :

1. Apakah elemen Modal Manusia (Human capital) berpengaruh terhadap kinerja perusahaan perbankan yang diukur dengan Return On Asset (ROA)?

2. Apakah elemen Modal Struktural ( Structural Capital) berpengaruh terhadap kinerja perusahaan perbankan yang diukur dengan Return On Asset (ROA)?

3. Apakah elemen Modal Pelayanan ( Customer Capital) berpengaruh terhadap kinerja perusahaan perbankan yang diukur Return On Asset (ROA)?

4. Apakah elemen Modal Manusia (Human Capital), Modal Struktural (Structural Capital) dan Modal Pelayanan ( Customer Capital) secara simultan berpengaruh terhadap kinerja perusahaan perbankan yang diukur dengan Return On Asset (ROA)? 


\section{KAJIAN PUSTAKA}

\subsection{Manajemen Keuangan}

Manajemen adalah usaha mencapai suatu tujuan tertentu melalui kegiatan orang lain. Dengan demikian manajer mengadakan koordinasi atas sejumlah aktivitas orang lain yang meliputi perencanaan, pengorganisasian, penggerakan dan pengendalian.(Menurut Harold Koontz dan Cyril O'donnel) dalam Umi Rusilowati, 2013:23).

Pengertian Manajemen Keuangan mengalami perkembangan mulai dari pengertian manajemen yang hanya mengutamakan aktivitas memperoleh dana saja sampai yang mengutamakan aktivitas memperoleh dan menggunakan dana serta pengelolaan terhadap aktiva. Khususnya penganalisisan sumber dana dan penggunaan-nya untuk merealisasikan keuntungan maksimum bagi perusahaan tersebut. Seorang manajemen keuangan harus memahami arus peredaran uang baik eksternal maupun internal.

Namun, Manajemen keuangan juga berkepentingan dengan penentuan jumlah aktiva yang layak dari investasi pada berbagai aktiva dan pemilihan sumber-sumber dana untuk membelanjai aktiva tersebut. Untuk memperoleh dana, manajer keuangan bisa memperolehnya dari dalam maupun luar perusahaan. Sumber dari luar perusahaan berasal dari pasar modal, bisa berbentuk hutang atau modal sendiri.

\subsection{Laporan Keuangan}

Laporan keuangan merupakan laporan tertulis yang memberikan informasi kuantitatif tentang posisi keuangan dan perubahan-perubahannya, serta hasil yang dicapai selama periode tertentu.Laporan keuangan dapat dijadikan media yang dapat dipakai untuk meneliti kondisi kesehatan perusahaan, dimana laporan keuangan tersebut terdiri dari neraca, perhitungan rugi laba, ikhtisar laba ditahan dan laporan posisikeuangan.Berikut ini merupakan pengertian dan definisi laporan keuangan dari berbagai sumber:

\subsection{Stakeholder Theory}

Penelitian ini didasarkan pada stakeholder theory, dimana teori ini lebih menitik beratkan pada posisi para stakeholder yang dipandang lebih memiliki pengaruh. Satu kesepakatan umum dalam teori stakeholder dimana laba akuntansi hanyalah merupakan ukuran return bagi pemegang saham (shareholder), sementara value added adalah ukuran yang lebih akurat yang diciptakan stakeholder dan kemudian disalurkan kepada stakeholder yang sama (Meek dan Gray, 1988 dalam Ulum, Ghozali dan Chariri 2008). Value added yang dipandang mempunyai ketepatan yang lebih tinggi dihubungkan dengan return yang dianggap sebagai ukuran bagi shareholder.

\subsection{Resource Based View (RBV)}

RBV merupakan sumber daya yang heterogen dan tidak dapat di transfer antar perusahaan tanpa biaya, sehingga sumber daya perusahaan akan berbeda 
sepanjang waktu (Sangkala, 2006:11). Penrose, 1959 dalam Juwita (2007) yang memandang perusahaan sebagai kumpulan sumber daya dan kemampuan.

\subsection{Teori Human Capital}

Teori ini pertama kali dikembangkan oleh Becker, yang mengemukakan bahwa investasi dalam pelatihan dan peningkatan sumber daya manusia merupakan investasi yang sangat penting (Becker, 1964 dalam Pratiwi 2005). Untuk memperoleh dan mempertahankan sumber daya, dibutuhkan seperangkat sumber daya fisik, keuangan serta organisasional khusus yang dapat menciptakan suatu keunggulan kompetitif (Wernefelt, 1984:174).

\subsection{Intellectual Capital (Modal Intelektual)}

Stewart (1997) dalam Sangkala (2006) menjelaskan bahwa Intellectual capital merupakan materi intelektual berupa informasi, pengetahuan, inovasi, intellectual, pengalaman, yang dapat dimanfaatkan dalam menghasilkan aset yang mempunyai nilai tambah dan memberikan keunggulan bersaing. Intellectual Capital meliputi penjumlahan atas keseluruhan pengetahuan yang dimiliki oleh perusahaan. Meritum (2003) dalam Sangkala (2006:37) berpendapat bahwa Intellectual Capital merupakan kombinasi manusia, sumber daya perusahaan dan relasi dari suatu perusahaan yang menunjukan bahwa nilai diciptakan melalui hubungan antara tiga kategori, yaitu modal manusia,structural dan relasi perusahaan. Hubungan yang baik antara ketiga kategori itu merupakan kunci dan sumber potensial untuk mendapatkan keunggulan kompetitif (sustainable competitive advantage) (Tayles et al. 2002; Hayton 2005 dalam Purnomosidhi, 2006). Sullivan (2000) dalam Sangkala (2006:36) yang menjelaskan Intellectual Capital sebagai proses transformasi pengetahuan menjadi suatu aset yang mampu memberikan nilai tambah bagi perusahaan.

\section{Komponen Intellectual Capital}

Bontis et al. (2000) menyatakan bahwa secara umum, para peneliti mengidentifikasi tiga konstruk utama dari modal intelektual, yaitu: human capital (HC), structural capital (SC), dan customer capital (CC). Menurut Bontis et al. (2000), secara sederhana HC merepresentasikan individual knowledge stock suatu organisasi yang direpresentasikan oleh karyawannya. HC merupakan kombinasi dari genetic inheritance; education; experience; and attitude tentang kehidupan dan bisnis.

Lebih lanjut Bontis et al. (2000) menyebutkan bahwa SC meliputi seluruh non-human storehouses of knowledge dalam organisasi. Termasuk dalam hal ini adalah database, organizational charts, process manuals, strategies, routines dan segala hal yang membuat nilai perusahaan lebih besar dari nilai materialnya.Customer Capital (CC) merupakan pengetahuan yang melekat dalam marketing channels dan customer relationship dimana suatu organisasi mengembangkan hal tersebut melalui proses berbisnis (Bontis et al., 2000).

Menurut Sangkala (2006:17), Intellectual Capital umumnya memiliki karakteristik sebagai berikut : Non Rivalreusm, Increasing Return, Non Additive. 
Banyak peneliti yang menyatakan bahwa intellectual capital terdiri dari tiga komponen utama (Stewart 1997, Sveiby 2001, Bontis 2000) yaitu :

1) Modal Manusia (Human Capital)

2) Modal Struktural (Strructural Capital)

3) Modal Pelanggan (Customer Capital)

\section{Peran Intellectual Capital}

Intellectual capital berperan penting dalam kegiatan bisnis perusahaan, hal tersebut dikarenakan intellectual capital memiliki beberapan kelebihan (Sangkala ;2006:16), yaitu

1) Memberikan pandangan menyeluruh mengenai perusahaan, karena tujuan utamanya adalah menciptakan suatu kerangka kerja yang dapat menjelaskan seluruh sumber daya perusahaan dan bagaimana sumber daya tersebut berinteraksi untuk menciptakan nilai.

2) Memberi dasar pengembangan pemahaman akan sifat dasar sumber daya dalam tindakan. Intellectual capital merupakan sumber daya yang memiliki perbedaan karakteristik bila dibandingkan dengan sumber daya fisik, yang menyebabkan adanya perbedaan dalam proses penciptaan nilai.

3) Menyediakan suatu bahasan yang sama mengenai intangible aset, memfasilitasi pemahaman mengenai sumbangannya terhadap penciptaan nilai di dalam dan antar perusahaan serta pada stakeholder.

4) Berfokus pada nilai, bukan pada biaya. Perspektif intellectual capital memiliki potensi untuk menciptakan nilai bagi perusahaan atau melakukan transformasi sebagai suatu tujuan, tanpa memperdulikan asal atau sumber daya tersebut, sehingga perspektif ini melengkapi kerangka kerja akuntansi.

5) Lebih bersifat praktek daripada konseptual, Intellectual capital memberikan dukungan berupa konsep, alat-alat dan kerangka kerja yang telah dikembangkan dalam suatu proses interaktif antara masyarakat praktisi dan akademisi, serta menggambarkan dengan jelas suatu pendekatan peneliti yang berorientasi pada praktek.

\section{Metode Pengukuran Intellectual Capital}

Suwarjono (2003) menyatakan bahwa metode pengukuran IC dikelompokan menjadi 2 kelompok yaitu : pengukuran non-monetary dan pengukuran monetary.

\section{Keterbatasan dalam pengukuran Intellectual Capital}

Kesulitan mengukur aset tidak berwujud dipandang sebagai suatu masalah karena menyebabkan manajemen tidak dapat efisien dalam mengelola intangible aset.

Hal tersebut terjadi karena adanya keterbatasan informasi yang menunjukan keberadaan intangible asset, sehingga laporan yang disajikan oleh perusahaan terkadang dinilai kurang relevan. Pulic (2000) mengungkapkan masalah yang mendasari keterbatasan pengukuran Intellectual Capital, yaitu :

1) Intellectual Capital masih tidak dianggap sebagi suatu sumber daya yang sederajat dengan modal fisik dan financial perusahaan. 
2) Adanya ketidaksesuaian antara model pengukuran terbaru dan system akuntansi yang berlaku.

\section{Pengaruh modal intelektual terhadap kinerja perusahaan}

Modal intelektual merupakan sumberdaya yang terukur untuk peningkatan competitive advantages, karena dengan Intellectual Capital perusahaan akan mampu menggunakan sumber daya perusahan secara efisiensi, ekonomis dan efektif, oleh karena itu modal intelektual akan memberikan kontribusi terhadap kinerja keuangan perusahaan (Harrison dan Sullivan, 2000, dalam Ulum, Ghozali dan Chariri, 2008). Human capital, structure capital dan customer capital sebagai konstruk utama pembentuk modal intelektual memiliki peran secara bersama dalam meningkatkan kinerja perusahaan. Sumber daya manusia (human capital) yang dimiliki oleh suatu perusahaan tidak akan bisa bekerja secara optimal tanpa didukung oleh sistem perusahaan (structural capital) yang baik, begitu sumber daya perusahaan yang berkualitas dan sistem perusahaan akan lebih sempurna apabila digunakan dengan maksimal akan membawa dampak pada peningkatan kinerja perusahaan yang lebih baik.

Oleh karena itu makin baik penggunaan modal intelektual sebuah perusahaan maka makin baik pula kinerja yang akan diperlihatkan oleh perusahaan tersebut.

\subsection{Value added intellectual coefficients (VAICTM)}

Model ini dimulai dengan kemampuan perusahaan untuk menciptakan value added. Value added (VA) merupakan efisiensi dari human capital (HC), structural capital (SC) dan capital employed (CE).

Hubungan dari VA dan capital employed (CE), dalam penelitian ini disebut VACA. VACA adalah indikator untuk VA yang diciptakan oleh satu unit dari physical capital. Pulic mengasumsikan bahwa jika 1 unit dari CE menghasilkan return yang lebih besar daripada perusahaan yang lain, berarti perusahaan tersebut lebih baik dalam memanfaatkan CE (dana yang tersedia). Hubungan selanjutnya adalah VA dan HC.Value added human capital (VAHU) menunjukkan berapa banyak VA dapat dihasilkan dengan dana yang dikeluarkan untuk tenaga kerja. VAHU mengindikasikan kemampuan dari HC untuk menciptakan nilai dalam perusahaan (Tan et al., 2007).Hubungan yang terakhir adalah structural capital coefficient (STVA) yang menunjukkan kontribusi structural capital (SC) dalam penciptaan nilai. STVA mengukur jumlah SC yang dibutuhkan untuk menghasilkan 1 rupiah dari VA, semakin besar kontribusi $\mathrm{HC}$ dalam value creation, maka akan semakin kecil kontribusi SC dalam hal tersebut. SC adalah VA dikurangi HC.Coefisien-coefisien yang telah dihitung sebelumnya akan dijumlahkan dan hasil penjumlahan tersebut diformulasikan dalam indikator yang baru yaitu VAICTM.

VAIC $^{\mathrm{TM}}$ mengindikasikan efisiensi penciptaan nilai perusahaan. Semakin tinggi nilai VAIC ${ }^{\mathrm{TM}}$ menunjukan bahwa perusahaan menggunakan aset Intellectual Capital- nya dengan lebih efisien (Pulic, 2000). 


\subsection{Kinerja Keuangan}

Pengertian lain tentang kinerja yaitu "Performance adalah ukuran seberapa efisien dan efektif sebuah organisasi atau seorang manager untuk mencapai tujuan yang memadai." (Stoner et al, 2000:9).

Kinerja keuangan mengukur kinerja perusahaan dalam memperoleh laba dan nilai pasar. Ukuran kinerja perusahaan biasanya diwujudkan dalam profitabilitas, pertumbuhan dan nilai pemegang saham. Kinerja perusahaan dalam penelitian ini diukur menggunakan ROA (Return On Asset).

ROA adalah rasio keuntungan bersih pajak yang juga berarti suatu ukuran untuk menilai seberapa besar tingkat pengembalian dari aset yang dimiliki perusahaan.(Bambang R, 1997).

\subsection{Hipotesis Penelitian}

Dengan menggunakan VAICTM yang diformulasikan oleh Pulic (1998; 1999; 2000) sebagai ukuran kemampuan intelektual perusahaan (corporate intellectual ability), diajukan hipotesis penelitian ini sebagai berikut:

1. Di duga elemen Modal Manusia (Human capital) berpengaruh signifikan terhadap kinerja perusahaan yang diukur dengan Return On Asset (ROA).

2. Di duga elemen Modal Struktural (Intellectual Capital) berpengaruh signifikan terhadap kinerja perusahaan yang diukur dengan Return On Asset (ROA).

3. Di duga elemen Modal Pelayanan ( Customer Capital) berpengaruh signifikan terhadap kinerja perusahaan yang diukur dengan Return On Asset (ROA).

4. Di duga elemen Modal Manusia (Human Capital), Modal Struktural (Structural Capital) dan Modal Pelayanan ( Customer Capital) secara simultan berpengaruh signifikan terhadap kinerja perusahaan yang diukur dengan Return On Asset (ROA).

\section{METODOLOGI PENELITIAN}

\subsection{Ruang LingkupPenelitian}

Penelitian ini dilakukan untuk mengetahui seberapa besar pengaruh Modal Manusia (Human Capital), Modal Struktural (Structural Capital), Modal Pelayanan (Service Capital/Customer Capital), sebagai variabel independen terhadap, Return On Asset (ROA) sebagai variabel dependen.

\subsection{Metode Penentuan Sampel}

Populasi dalam penelitian ini, yaitu perusahaan perbankan yang terdaftar di BEI dengan periode observasi tahun 2010 -2014. Jenis penelitian yang digunakan dalam penelitian ini adalah explorative yang ingin mengembangkan teori melalui formulasi pengujian dan pengembangan ulang preposisi selama penyusunan teori yang bersifat grounded. Peneliti ingin berusaha untuk mengkonstruksi suatu metode ukuran kinerja IC untuk perusahaan perbankan yang terdaftar di BEI 
dengan melakukan kajian mendalam terhadap metode penilaian yang telah ada $\left(\mathrm{VAIC}^{\mathrm{tm}}\right)$ dan disesuaikan dengan akun akun laporan keuangan perusahaan.

\subsection{Variabel dan Pengukuran}

Variabel yang diukur dalam penelitian ini adalah sebagai berikut :

\subsubsection{Variabel Independen}

Yang digunakan adalah intellectual capital yang diukur dengan VAIC ${ }^{\mathrm{TM}}$. Tahapan perhitungan VAIC ${ }^{\mathrm{TM}}$ adalah sebagai berikut, (Rehmanet.al, 2012) :

1) Value Added (VA) diukur dengan :

$$
\text { VA = OUTPUT }- \text { INPUT }
$$

Dimana:

Output : Total penjualan

Input : Total beban

Value added : Selisih antara output dan input

2) Human Capital Efficiency (HCE) diukur dengan

$$
\mathrm{HCE}=\mathrm{VA} \div \mathrm{HC}
$$

Dimana :

HCE : Human Capital Efficiency

VA : Value added

HC : Human Capital: Beban karyawan

3) Structural Capital Efficiency (SCE) diukur dengan :

SCE $=$ SC $\div$ VA

Dimana :

SCE : Structural Capital Efficiency

SC : Structural Capital : VA - HC

VA : Value Added

4) Capital Employed Efficiency (CEE) diukur dengan :

$$
\mathrm{CEE}=\mathrm{VA} \div \mathrm{CE}
$$

Dimana :

CEE Capital Employed Efficiency
VA : Value Added
CE : Capital Employed = dana yang tersedia
(ekuitas,lababersih)


5) Value Added Intellectual Coefficient (VAIC ${ }^{\mathrm{TM}}$ ) diukur dengan:

$$
\mathrm{VAIC}=\mathrm{HCE}+\mathrm{SCE}+\mathrm{CEE}
$$

\subsubsection{Variabel Dependen}

Yang digunakan dalam penelitian ini adalah financial performance yang diukur dengan menggunakan (Return On Aset) ROA (Dadashinasab et.al, 2012) (Wira 2011:76):

Return On Assets (ROA) diukur dengan :

Mencerminkan seberapa besar laba yang bisa didapat perusahaan dengan menggunakan seluruh asetnya.

$$
\text { ROA = Laba Bersih /Total Aset }
$$

\section{HASIL PENELITIAN DAN PEMBAHASAN}

\subsection{Analisis Statistik Desktiptif dan Uji Asumsi Klasik \\ 4.1.1 Multikolinieritas}

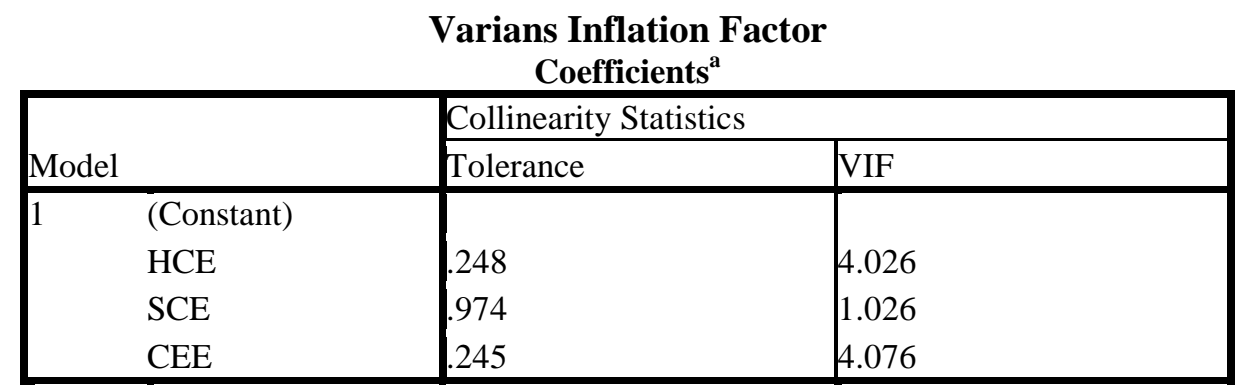

a. Dependent Variable: ROA

Dari tabel VIF (Variance Inflation Factor) diperoleh nilai tolerance semua variabel independen lebih besar dari 0,10 dan nilai VIF semua variabel independen lebih kecil dari 10, sehingga pada data tidak terjadi multikolinearitas. Autokorelasi

\section{Durbin Watson}

Model Summary ${ }^{\mathrm{b}}$

\begin{tabular}{|l|l|l|l|l|l|}
\hline Model & $\mathrm{R}$ & $\mathrm{R}$ Square & $\begin{array}{l}\text { Adjusted } \\
\text { Square }\end{array}$ & $\begin{array}{l}\text { R Std. Error of the } \\
\text { Estimate }\end{array}$ & $\begin{array}{l}\text { Durbin- } \\
\text { Watson }\end{array}$ \\
\hline 1 & $.462^{\mathrm{a}}$ & .214 & .192 & .00677 & 1.813 \\
\hline
\end{tabular}

a. Predictors: (Constant), CEE, SCE, HCE

b. Dependent Variable: ROA

Hasil Uji DurbinWatson pada analisa regresi (tabel 4.7) adalah 1,813, dimana $d u=1,7455$, sedangkan 4-1,7455 = 2,2545 sehingga $d w=d_{u}<D W<4-d_{u}$ $/ 1,7455<1,813<2,2545$ pada model regresi ini tidak terjadi autokorelasi. 


\title{
4.1.2 Pengujian Model Regresi Data Panel
}

\author{
Redundant Fixed Effects Tests \\ Pool: ARWIJOSS \\ Test cross-section fixed effects
}

\section{Uji Chow}

\begin{tabular}{llll}
\hline \hline Effects Test & Statistic & d.f. & Prob. \\
\hline \hline Cross-section F & 21.484867 & $(21,85)$ & 0.0000 \\
Cross-section Chi-square & 202.600506 & 21 & 0.0000 \\
\hline \hline
\end{tabular}

Hasil pengujian tabel diatas dapat terlihat bahwa nilai probabilitas cross section adalah 0.0000 atau $<0,05$, maka Ho ditolak dan menerima $\mathrm{H} 1$ berarti menggunakan pendekatan fixed effect.

\section{Uji Hausman}

Correlated Random Effects - Hausman Test

Pool: ARWIJOSS

Test cross-section random effects

\begin{tabular}{lcll}
\hline \hline & \multicolumn{2}{c}{ Chi-Sq. } & \\
Test Summary & \multicolumn{2}{c}{ Statisti } & \\
c & Chi-Sq. d.f. & Prob. \\
\hline \hline Cross-section random & 16.192408 & 3 & 0.0010 \\
\hline \hline
\end{tabular}

Hasil penelitian diatas dapat terlihat bahwa nilai probabilitas cross section adalah 0,0010 atau < 0,05, maka Ho ditolak dan menerima H1 , berarti menggunakan pendekatan fixed effect.

Dari kedua model yang digunakan yaitu uji chow dan uji hausman menunjukkan hasil yang konsisten dengan mengikuti fixed effect model regression, dengan demikian model regresi yang digunakan adalah model fixed effect model.

\subsubsection{Persamaan Model Regresi}

Penelitian dengan regresi data panel ini digunakan untuk melihat pengaruh dari variabel independen Elemen Modal Manusia (Human capital), Elemen Modal Struktural (Structural Capital), Elemen Modal Pelayanan (Customer Capital) terhadap variabel dependen Return On Asset (ROA), dengan menggunakan perangkat lunak eviews, hasilnya ditunjukkan oleh tabel berikut:

\section{Model Regresi}

\begin{tabular}{lllll}
\hline \hline Variable & Coefficient & Std. Error & t-Statistic & Prob. \\
\hline \hline HCE? & -0.000477 & 0.000362 & -1.318045 & 0.1910 \\
SCE? & $5.99 E-06$ & $1.46 E-05$ & 0.409528 & 0.6832 \\
CEE? & 0.012875 & 0.003752 & 3.431473 & 0.0009
\end{tabular}




\begin{tabular}{lllll} 
C & 0.014998 & 0.000488 & 30.73666 & 0.0000 \\
R-squared & 0.879070 & Mean dependent var & 0.016418 \\
Adjusted R-squared & 0.844924 & S.D. dependent var & 0.007520 \\
S.E. of regression & 0.002962 & Akaike info criterion & -8.609519 \\
Sum squared resid & 0.000745 & Schwarz criterion & -7.995774 \\
Log likelihood & 498.5236 & Hannan-Quinn criter. & -8.360581 \\
F-statistic & 25.74514 & Durbin-Watson stat & 1.850189 \\
Prob(F-statistic) & 0.000000 & & \\
\hline \hline
\end{tabular}

Sumber :Output Eviews

Dependent Variable: ROA?

Method: Pooled Least Squares

Date: 01/11/16 Time: 00:42

Sample: 20102014

Included observations: 5

Cross-sections included: 22

Total pool (balanced) observations: 110

Berdasarkan hasil regresi diatas maka diperoleh persamaan regresi linear berganda sebagai berikut:

$\mathrm{Y}=0,015-0,00047 \mathrm{X}_{1}+5,99 \mathrm{X}_{2}+0,0128 \mathrm{X}_{3}+$ eit

Dari persamaan diatas dapat dijelaskan sebagai berikut:

a. Konstanta sebesar 0.015 menunjukkan bahwa jika variable independen yaitu

Elemen Modal Manusia (Human capital), Elemen Modal Struktural (Structural Capital), Elemen Modal Pelayanan (Customer Capital) pada observasi ke-i dan periode ke - $\mathrm{t}$ adalah nol, maka nilai variable dependent yaitu Return On Asset (ROA) adalah 0,015.

b. Koefisien regresi sebesar -0,000477 menunjukkan bahwa jika nilai Elemen Modal Manusia (Human capital) turun sebesar $1 \%$ maka nilai Return On Asset (ROA) akan meningkat sebesar 0,047 point. Dari tanda negatif pada angka 0,000477 menunjukkan bahwa hubungan yang terjadi antara Elemen Modal Manusia (Human capital) dengan Return On Asset (ROA) adalah berlawanan arah atau negatif.

c. Koefisien regresi sebesar 5,990 menunjukkan bahwa jika nilai Elemen Modal Struktural (Structural Capital) naik sebesar 1\% maka nilai Return On Asset (ROA) akan naik sebesar 5990 point. Dari tanda positif pada angka 5,990 menunjukkan bahwa hubungan yang terjadi antara Elemen Modal Struktural (Structural Capital) dengan Return On Asset (ROA) adalah searah arah atau positif.

d. Koefisien regresi sebesar 0,0128 menunjukkan bahwa jika Elemen Modal Pelayanan (Customer Capital) naik sebesar 1\% maka nilai Return On Asset (ROA) akan naik sebesar 0,0128 point. Dari tanda positif pada angka 0,0128 menunjukkan bahwa hubungan yang terjadi antara Elemen Modal Pelayanan (Customer Capital) dengan Return On Asset (ROA) adalah searah atau positif.

\subsection{Pengujian Hipotesis}

\subsubsection{Uji t}

Hasil Uji t dari pengaruh Elemen Modal Manusia (Human Capital) terhadap Return On Asset (ROA) dapat dilihat pada tabel ini. 


\section{Hasil Uji t (Elemen Modal Manusia (Human Capital) terhadap ROA)}

\begin{tabular}{lcccc}
\hline \hline Variable & Coefficient & Std. Error & t-Statistic & Prob. \\
\hline \hline C & & & & \\
HCE? & 0.015674 & 0.000472 & 33.21081 & 0.0000 \\
& 0.000489 & 0.000240 & 2.034621 & 0.0449 \\
R-squared & & & & \\
Adjusted R-squared & 0.861798 & Mean dependent var & 0.016418 \\
S.E. of regression & 0.826851 & S.D. dependent var & 0.007520 \\
Sum squared resid & 0.003129 & Akaike info criterion & -8.512384 \\
Log likelihood & 4900852 & Schwarz criterion & -7.947738 \\
F-statistic & 24.65975 & Hannan-Quinn criter. & -8.283361 \\
Prob(F-statistic) & 0.000000 & Durbin-Watson stat & 1.528816 \\
& & & \\
\end{tabular}

Dependent Variable: ROA?

Method: Pooled Least Squares

Date: 01/14/16 Time: 01:30

Sample: 20102014

Included observations: 5

Cross-sections included: 22

Total pool (balanced) observations: 110

Hasil pengujian dengan analisa regresi data panel menunjukkan hasil $t_{\text {hitung }}$ untuk variabel independen Elemen Modal Manusia (Human Capital) adalah sebesar 2.034621, sementara nilai $t_{\text {tabel }}$ dengan derajat kebebasan/ degree of freedom $(\mathrm{df})=5 \%, \mathrm{df}=\mathrm{n}-\mathrm{k}=110-2=108$, diperoleh nilai $\mathrm{t}_{\text {tabel }}$ adalah 1,982. Sehingga $t_{\text {hitung }}>t_{\text {tabel }}$ yaitu 2.034621 $>1,982$, hal ini menunjukkan $\mathrm{H}_{0}$ ditolak dan $\mathrm{H}_{1}$ diterima (dimana $\mathrm{H}_{1}$ menunjukkan ada pengaruh yang signifikan secara parsial dan $\mathrm{H}_{0}$ tidak ada pengaruh yang signifikan secara parsial), yang menunjukkan bahwa ada pengaruh dari Elemen Modal Manusia (Human Capital) terhadap Return On Asset (ROA).

Dari nilai probabilitas diperoleh hasil 0,0449 yang menunjukkan lebih kecil dari 0,05 atau $0,0449<0,05$, hal ini menunjukkan juga $\mathrm{H}_{0}$ ditolak dan $\mathrm{H}_{1}$ diterima, yang menunjukkan bahwa ada pengaruh yang signifikan dari Elemen Modal Manusia (Human Capital)terhadap Return On Asset (ROA).

Nilai Adjusted R-squared sebesar 0.826851 berarti variabel Elemen Modal Manusia (Human Capital) bisa menjelaskan atau berkontribusi secara partial sebesar $82,69 \%$. Sedangkan sisanya $(100 \%-82,96 \%=7,31 \%)$ dijelaskan oleh sebab lain. Persamaan regresi dari hasil Uji t ini adalah:

$$
\mathrm{Y}=0.015674+0.000489 \mathrm{X} 1+\mathrm{e}
$$

Arti dari persamaan regresi diatas adalah jika Elemen Modal Manusia (Human Capital) adalah 0 maka Return On Asset (ROA) adalah 0.015674. Jika Elemen Modal Manusia (Human Capital) n aik 1\% maka Return On Asset (ROA) akan naik 0,000489 Point. 


\section{Hasil Uji t (Elemen Modal Struktural (Structural Capital) terhadap ROA)}

\begin{tabular}{lcccc} 
Variable & Coefficient & Std. Error & t-Statistic & Prob. \\
\hline \hline C & 0.016416 & 0.000305 & 53.84456 & 0.0000 \\
SCE? & $8.76 E-06$ & $1.58 E-05$ & 2.555758 & 0.0479 \\
R-squared & 0.855734 & Mean dependent var & 0.016418 \\
Adjusted R-squared & 0.819253 & S.D. dependent var & 0.007520 \\
S.E. of regression & 0.003197 & Akaike info criterion & -8.469443 \\
Sum squared resid & 0.000889 & Schwarz criterion & -7.904797 \\
Log likelihood & 488.8193 & Hannan-Quinn criter. & -8.240419 \\
F-statistic & 23.45702 & Durbin-Watson stat & 1.480317 \\
Prob(F-statistic) & 0.000000 & & \\
\hline \hline
\end{tabular}

\begin{tabular}{ll}
\hline Dependent Variable: ROA? & Sample: 2010 2014 \\
Method: Pooled Least Squares & Included observations: 5 \\
Date: 01/14/16 Time: 01:31 & Cross-sections included: 22 \\
Total pool (balanced) observations: 110 &
\end{tabular}

Hasil pengujian dengan analisa regresi data panel menunjukkan hasil $t_{\text {hitung }}$ untuk variabel independen Elemen Modal Struktural (Structural Capital) adalah sebesar 2.555758, sementara nilai t tabel dengan derajat kebebasan/ degree of freedom $(\mathrm{df})=5 \%$, df $=\mathrm{n}-\mathrm{k}=110-2=108$, diperoleh nilai t tabel adalah 1,982. Sehingga $t_{\text {hitung }}>t_{\text {tabel }}$ yaitu 2.555758>1,982, hal ini menunjukkan $\mathrm{H}_{1}$ diterima dan $\mathrm{H}_{0}$ ditolak (dimana $\mathrm{H}_{1}$ menunjukkan ada pengaruh yang signifikan secara parsial dan $\mathrm{H}_{0}$ tidak ada pengaruh yang signifikan secara parsial), dari hasil uji menunjukkan bahwa ada pengaruh yang signifikan dari Elemen Modal Struktural (Structural Capital) terhadap Return On Asset (ROA).

Dari nilai probabilitas diperoleh hasil 0.0479 yang menunjukkan lebih kecil dari 0,05 atau $0,0479<0,05$, hal ini menunjukkan juga $\mathrm{H}_{0}$ diterima dan $\mathrm{H}_{1}$ ditolak, yang menunjukkan bahwa ada pengaruh yang signifikan dari Elemen Modal Struktural (Structural Capital) terhadap Return On Asset (ROA).

Nilai Adjusted R-squared sebesar 0.819253 berarti variabel Elemen Modal Struktural (Structural Capital) bisa menjelaskan variabel Return On Asset (ROA) sebesar $81,82 \%$. Sedangkan sisanya $(100 \%-81,82 \%=18,18 \%)$ dijelaskan oleh sebab lain. Persamaan regresi dari hasil Uji t ini adalah:

$\mathrm{Y}=0,016416+8,760000 \mathrm{X} 2+\mathrm{e}$

Arti dari persamaan regresi diatas adalah jika Elemen Modal Struktural (Structural Capital) adalah 0 maka Return On Asset (ROA) adalah 0,016416. Jika Elemen Modal Struktural (Structural Capital) naik 1\% maka Return On Asset (ROA) akan naik 8,760 point. 


\section{Hasil Uji t (Elemen Modal Pelayanan (Customer Capital)terhadap ROA)}

\begin{tabular}{lcccc}
\hline \hline Variable & Coefficient & Std. Error & t-Statistic & Prob. \\
\hline \hline C & 0.014908 & 0.000483 & 30.83820 & 0.0000 \\
CEE? & 0.009065 & 0.002356 & 3.848587 & 0.0002 \\
R-squared & 0.876285 & Mean dependent var & 0.016418 \\
Adjusted R-squared & 0.845000 & S.D. dependent var & 0.007520 \\
S.E. of regression & 0.002961 & Akaike info criterion & -8.623115 \\
Sum squared resid & 0.000763 & Schwarz criterion & -8.058469 \\
Log likelihood & 497.2713 & Hannan-Quinn criter. & -8.394092 \\
F-statistic & 28.01032 & Durbin-Watson stat & 1.646927 \\
Prob(F-statistic) & 0.000000 & & \\
\hline \hline
\end{tabular}

Dependent Variable: ROA?

Sample: 20102014

Method: Pooled Least Squares

Included observations: 5

Date: 01/14/16 Time: 01:32

Cross-sections included: 22

Total pool (balanced) observations: 110

Hasil pengujian dengan analisa regresi data panel menunjukkan hasil $t_{\text {hitung }}$ untuk variabel independen Elemen Modal Pelayanan (Customer Capital) adalah sebesar 3.848587, sementara nilai $t_{\text {tabel }}$ dengan derajat kebebasan/degree of freedom $(\mathrm{df})=5 \%, \mathrm{df}=\mathrm{n}-\mathrm{k}=110-2=108$, diperoleh nilai $\mathrm{t}$ tabel adalah 1,982. Sehingga $t_{\text {hitung }}>t_{\text {tabel }}$ yaitu $3.848587>1,982$, hal ini menunjukkan $\mathrm{H}_{1}$ diterima dan $\mathrm{H}_{0}$ ditolak (dimana $\mathrm{H}_{1}$ menunjukkan ada pengaruh secara parsial dan $\mathrm{H}_{0}$ tidak ada pengaruh secara parsial), yang menunjukkan bahwa ada pengaruh dari Elemen Modal Pelayanan (Customer Capital) terhadap Return On Asset (ROA).

Dari nilai probabilitas diperoleh hasil 0,0002 yang menunjukkan lebih kecil dari 0,05 atau $0,0002<0,05$, hal ini menunjukan juga $\mathrm{H}_{1}$ diterima dan $\mathrm{H}_{0}$ ditolak, yang menunjukkan bahwa ada pengaruh yang signifikan dari Elemen Modal Pelayanan (Customer Capital) terhadap Return On Asset (ROA).

Nilai Adjust $R$-squared sebesar 0,845000 berarti variabel Elemen Modal Pelayanan (Customer Capital) bisa menjelaskan variabel Return On Asset (ROA) sebesar $84,50 \%$. Sedangkan sisanya $(100 \%-84,50 \%=15,50 \%)$ dijelaskan oleh sebab lain. Persamaan regresi dari hasil Uji t ini adalah:

$\mathrm{Y}=0.014908+0.009065 \mathrm{X} 3+\mathrm{e}$

Arti dari persamaan regresi diatas adalah jika Elemen Modal Pelayanan (Customer Capital) adalah 0 maka Return On Asset (ROA) adalah 0,014908. Jika Biaya Elemen Modal Pelayanan (Customer Capital) naik 1\% maka Return On Asset (ROA) akan naik 0,00906 Point.

\subsubsection{Uji F}

Berdasarkan hasil output Eviews ditunjukkan tabel diatas, nilai $\mathrm{F}_{\text {hitung }}$ yaitu sebesar 25.74514, sementara $\mathrm{F}_{\text {tabel }}$ dengan tingkat signifikansi atau probabilitas $5 \%$, df) $=\mathrm{k}-1=4$ dan $\mathrm{df} 2=\mathrm{n}-\mathrm{k}=110-5=105$, didapat $\mathrm{F}$ tabel sebesar 2,40. Dengan demikian $F_{\text {hitung }}>F_{\text {tabel }}(25.74514>2,40)$, kemudian dilihat dari nilai Probabilitas $\left(\mathrm{F}_{\text {-statistic }}\right)$ adalah 0,0000, lebih kecil dari 0,05 atau 0,0000 $<0,05$, 
sehingga $\mathrm{H}_{0}$ ditolak dan $\mathrm{H}_{1}$ diterima. Hal ini bahwa variabel Elemen Modal Manusia (Human capital), Elemen Modal Struktural (Structural Capital), Elemen Modal Pelayanan (Customer Capital) secara simultan (bersama-sama) mempunyai pengaruh yang signifikan terhadap Return On Asset (ROA).

\subsubsection{Koefisien Determinasi (Adjusted R-Square)}

Berdasarkan tabel diatas besarnya angka koefisien determinasi $(R 2)$ adalah 0.844924 . Hal ini menunjukkan bahwa persentase sumbangan pengaruh variabel independen terhadap variabel dependen adalah sebesar $84,49 \%$, atau dapat diartikan bahwa variabel independen yang digunakan dalam model mampu menjelaskan sebesar $84,49 \%$ terhadap variabel dependennya. Sedangkan sisanya $5,51 \%$ lainnya dipengaruhi faktor makro lainnya di luar model regresi tersebut.

\section{KESIMPULAN DAN SARAN}

\subsection{Kesimpulan}

Berdasarkan hasil pengujian dan pembahasan sebagaimana telah disajikan pada bagian sebelumnya, maka dapat ditarik beberapa kesimpulan :

1. Human Capital (Modal Manusia) berpengaruh positif dan signifikan terhadap Return On Asset (ROA), karena nilai $t$ hitung $t_{\text {hitung }}>t_{\text {tabel }}$ yaitu 2.034621> 1,982, dan Nilai koefisien determinasi sebesar 0.826851 berarti variabel Elemen Modal Manusia (Human Capital) bisa menjelaskan atau berkontribusi secara partial sebesar 82,69\%. Sedangkan sisanya (100\% $82,96 \%=7,31 \%$ ) dijelaskan oleh sebab lain. dengan Persamaan regresi : $\mathrm{Y}=0.015674+0.000489 \mathrm{X} 1+\mathrm{e}$

2. Structural Capital (Modal Struktural) berpengaruh positif dan signifikan terhadap Return On Asset (ROA), karena nilai t hitung $t_{\text {hitung }}>t_{\text {tabel }}$ yaitu 2.555758> 1,982, dan nilai Nilai koefisien determinasi sebesar 0.819253 berarti variabel Elemen Modal Struktural (Structural Capital) bisa menjelaskan variabel Return On Asset (ROA) sebesar 81,82\%. Sedangkan sisanya $(100 \%-81,82 \%=18,18 \%)$ dijelaskan oleh sebab lain. Persamaan regresinya adalah :

$\mathrm{Y}=0,016416+8,760000 \mathrm{X} 2+\mathrm{e}$

3. Customer Capital (Modal Pelayanan) berpengaruh positif dan signifikan terhadap Return On Asset (ROA), karena nilai t hitung $t_{\text {hitung }}>t_{\text {tabel }}$ yaitu $3.848587>1,982$ dan Nilai koefisien determinasi sebesar 0,845000 berarti variabel Elemen Modal Pelayanan (Customer Capital) bisa menjelaskan variabel Return On Asset (ROA) sebesar 84,50\%. Sedangkan sisanya (100\% $-84,50 \%=15,50 \%$ ) dijelaskan oleh sebab lain. Persamaan regresinya : $\mathrm{Y}=0.014908+0.009065 \mathrm{X} 3+\mathrm{e}$

4. Elemen Modal Manusia (Human Capital), Modal Struktural (Structural Capital) dan Modal Pelayanan ( Customer Capital) secara simultan bersamasama berpengaruh terhadap Return On Asset (ROA). Dengan hasil output Eviews nilai $F_{\text {hitung }}$ yaitu $F_{\text {hitung }}>F_{\text {tabel }}(25.74514>2,40)$, Nilai koefisien 
determinasi diperoleh sebesar 84,49\%, artinya variabel Return On Asset (ROA) bisa dijelaskan secara simultan oleh variabel

Elemen Modal Manusia (Human Capital), Modal Struktural (Structural Capital) dan Modal Pelayanan ( Customer Capital) sebesar 84,49\% dan sisanya sebesar $15,51 \%$ dijelaskan oleh sebab lain, dengan persamaan regresi sebagai berikut:

$Y=0,015-0,00047 X_{1}+5,99 X_{2}+0,0128 X_{3}+$ cit.

Dengan kata lain, profitabilitas suatu perusahaan secara positif dipengaruhi oleh peningkatan efisiensi penciptaan nilai dari intellectual capital. Selain itu, hasil dari penelitian ini dapat digunakan oleh manajer di perusahaan sebagai pertimbangan untuk memanfaatkan serta mengelola intellectual capital yang dimiliki dalam menghasilkan keuntungan perusahaan.

\subsection{Saran}

Untuk perbaikan penelitian serupa yang dapat dijadikan acuan bagi peneliti yang akan datang antara lain a) untuk penelitian selanjutnya, dapat menambahkan indikator variabel dependen dengan Market to book value ratios of equity $(M / B)$, Return on Equity (ROE), Growth in revenues (GR) dan Employee productivity (EP) seperti penelitian yang dilakukan oleh Chen (2005) dan juga Asset Turnover (ATO) pada penelitian Firer dan William (2003) , b) metode analisis dapat dilakukan pula melalui metode Partial Least Square (PLS.

\section{DAFTAR PUSTAKA}

Abdol mohammadi, M.J. 2005.“Intellectual capital disclosure and market capitalization".Journal of Intellectual Capital.Vol.6 No. 3. pp. 397-416.

Astuti, P.D. dan A. Sabeni. 2005. "Hubungan Intellectual Capital dan Business Performance”. Proceeding SNA VII. Solo. pp. 694-707

Bank Indonesia.2007.Statistik Perbankan Indonesia.Direktorat Perizinan dan Informasi Perbankan Bank Indonesia. Jakarta.

Ghozali, I. 2006. Structural Equation Medeling; Metode Alternatif dengan PLS. Badan Penerbit Undip. Semarang.

Ikatan Akuntan Indonesia.2002.Pernyataan Standar Akuntansi Keuangan No. 19.Salemba Empat. Jakarta

Imam Ghozali. 2008. Structural Equation Modeling Metode Alternatif dengan Partial Least Square (PLS). Badan Pnerbit Universitas Diponegoro. Semarang.

Kurniawan, G.R, Penulisan Ilmiah Tentang Analisis Rasio Likuidita, Solvabilitas, aktivitas dan Profitabilitas pada Perusahaan telekomunikasi Indonesia dan PT. Indosat, Tbk,http://library.gunadarma.ac.id//repository/view /357/-.html.

Masturina A, (2010) Analisis Pengelolaan Modal Kerja, Likuiditas, Solvabilitas, dan aktivitas terhadap Rentabilitas pada Perusahaan Property yang terdaftar Di BEI,SkripsiJurusan manajemen dan bisnis UIN Jakarta. 
Ramayanti, T.Y. (2013). Tesis tentang Analisis Laporan Keuangan Sebagai salah satu alat untuk menilai tingkat keberhasilan Kinerja KeuanganManajemen pada CV. Kasur Achmad Syukri. Pascasarjana Universitas Bina Darma, Palembang.

Riduwan,(2010), Metode dan Tehnik Menyusun Tesis, Alfabeta, Bandung.

Sawarjuwono, T. 2003. "Intellectual capital: perlakuan, pengukuran, dan pelaporan (sebuah library research)". Jurnal Akuntansi dan Keuangan.Vol.5 No. 1. pp. 35-57.

Setiarso, B. 2006."Pengelolaan Pengetahuan (Knowledge Management) dan Modal Intelektual (Intellectual Capital) Untuk Pemberdayaan UKM".available online at: www.ilmukomputer.com (accessed April 2007).

Sugiyono, (2013) Metode Penelitian Manajemen Pendekatan Kuantitatif,Kualitatif, Kombinasi (Mixed Methods), Penelitian Tindakan (Action Research), Penelitian Evaluasi. Penerbit Alfabeta, Bandung.

Sugiyono, (2013)Metode Penelitian Kuantitatif, Kualitatif dan $R \quad \& \quad D$, PenerbitAlfabeta, Bandung

Suseno dan P. Abdullah. 2003. Sistem dan Kebijakan Perbankan di Indonesia. Seri Kebanksentralan No. 7.Pusat Pendidikan dan Studi Kebanksentralan (PPSK) Bank Indonesia. Jakarta.

Tim Penyusunan Tesis, (2013) Buku Panduan Penulisan Tesis, Program Pascasarjana Universita Pamulang.

Ulum, Ihyaul, I. Ghozali dan A. Chariri, (2008).“Intellectual Capital Dan Kinerja Keuangan Perusahaan; Suatu Analisis Dengan Pendekatan Partial Least Squares".Simposium Nasional Akuntansi XI: Pontianak, 23-25 Juli 2008.

Widhi Widyasari , Dra. Rodhiyah, SU dan Dra. Apriatni E. P, M.Si, Jurnal http://www.fisip.ac. Email: administrasi.bisnis@undip.ac.id, 18 April 2014.

Yulivani, D.P, Penulisan Ilmiah tentang Analisis Likuiditas, Solvabilitas dan Rentabilitas laporan keuanganPT Colorpark Indoensia, Tbk dan Anak Perusahaanhttp://www.google.com/search?q=.contoh 